\title{
Ressentiment - The History of the Theory: On Interdisciplinarity of Security Studies
}

\author{
Resentyment - historia teorii. Rzecz o interdyscyplinarności badań \\ nad bezpieczeństwem
}

\section{- Abstrakt •}

Artykuł zawiera próbę prezentacji historii badań nad resentymentem w celu naświetlenia znaczenia tej problematyki dla nauk o bezpieczeństwie (w szczególności dla analiz szerokiego spektrum zagadnień związanych z ideologicznie motywowaną przemoca). Nawet pobieżny przegląd wykorzystania stworzonej przez Fryderyka Nietzschego koncepcji ressentiment w naukach społecznych i humanistycznych pozwala wyprowadzić istotne wnioski na temat znaczenia interdyscyplinarności w rozwoju refleksji nad bezpieczeństwem. Ich prezentacja jest najistotniejszym celem niniejszego artykułu.

Słowa kluczowe: Nietzsche; przemoc; resentyment; studia nad bezpieczeństwem

\section{- Abstract •}

The paper presents a brief history of ressentiment (resentment) research in order to shed some light on the importance of these considerations for Security Studies (particularly for the analyses of the broad spectrum of issues related to ideologically motivated violence). Even a cursory overview of the usage of the created by Friedrich Nietzsche concept of ressentiment in social sciences and humanities enables to draw significant conclusions on the importance of interdisciplinarity in the development of reflection on security. Presentation of those conclusions is the main goal of this article.

Keywords: Nietzsche; violence; ressentiment; Security Studies

The ressentiment category has not, so far, enjoyed a particular interest in the contemporary Polish research on security. The reason for such a state of affairs has its source in both the lack of knowledge on the phenomenon of ressentiment, as well as in the belief that the problematic aspects of ressentiment can only be addressed by psychological studies. That belief does not seem right. I will try, in this paper, 
to demonstrate that these aspects go beyond a narrow domain of psychology and that this category is of a very interdisciplinary nature, and hence can be successfully adopted for describing many complex social phenomena, including the ones Security Studies are interested in. It is an important issue because, in my opinion, the ressentiment phenomenon is particularly dangerous and may present a risk for particular individuals affected by ressentiment, but also for whole societies. It is, furthermore, a very complicated phenomenon and that is why it should be examined by many academic disciplines.

In spite of the fact that the goal of my article was reaching an objective truth, in the process I have tried not to impose on myself in advance any universal methodological standards, which would later force me to formulate certain theoretical judgments, with regard to, for example, the choice and number of the methods used, as well as the accepted theoretical conceptualizations. In the research practice it means adopting an attitude close to theoretical pluralism, but without the voluntarist anarchism characteristic to it. Such an attitude is defined, above all, by the openness to the multitude of alternative grasps of the research problems, which serve as both external standards of criticism, and imagination extending "orientation points". It is also defined by the fact that it allows the possibility to change the methodology, even while conducting the research procedures. A philosophical basis of this approach is the Feyerabendian view that bias is uncovered not by analysis but by contrast (Feyerabend, 2001, p. 30). This is why the multiplicity of various methodological or theoretical approaches, even if they are adopted only for a while, will neither impoverish nor obfuscate the final picture; on the contrary, they will enrich and clarify it by bringing in a particular epistemological perspectivism that allows to grasp the reality in the multifaceted light of truth. The consequences of adopting such a cognitive attitude in my research were twofold. First, I decided to go beyond a simple monistic perspective that inclines the researcher to depict the phenomenon from the point of view of only one discipline. Second, it was my intention to come up with a non-one-dimensional depiction that would be created through many dimensions and many domains, especially philosophy, political science, and sociology.

Now, what is ressentiment? We should start with an elucidation of the genealogy of the concept. The term 'ressentiment' stems from French. In the $15^{\text {th }}$ century, it had neutral connotations and meant a repeatedly experienced feeling. A negative aspect of ressentiment, related to a "spiritual" or "moral" suffering, came forth later on, in the $16^{\text {th }}$ century. This additional meaning was given by Michel de Montaigne, according to whom the term defines a constantly lingering feeling, which is chiefly constituted by the desire for revenge and repulsive recall- 
ing of the formerly experienced suffering ${ }^{1}$. However, in that time, the term did not possess an academic and theoretical importance. It gained it at the end of the $19^{\text {th }}$ century, thanks to a German thinker - Friedrich Nietzsche. He is the reason why ressentiment is understood today as a complex of (always hidden) hateful emotions, like jaundice, jealousy, lust for revenge, which emerge when, due to an important reason, one feels inferior. Sometimes this complex of emotions may arise due to experienced humiliation, although it is not necessary. Much more often we ourselves are the generator of ressentiment. It comes to being as a result of comparing oneself with others, i.e., when in the outcome of that process we feel inferior to them. Such inferiority undermines the value of our self and in result generates hatred, jealousy, jaundice, or hostility (i.e., the emotions that majority of ethical systems try to ineffectually tame).

The way Nietzsche understands ressentiment is quite complex. Slightly simplifying it, what one may find there are two levels of analysis of the ressentiment phenomenon - psychological and historiosophical-cultural (Nietzsche, 1996). At the former level, Nietzsche addresses the psychological (personal) causes of the emergence of ressentiment - for, according to him, a particular psychophysical structure is always a generator of deprivation in ressentiment, not the external (social, political, or situational) factors. On the second level, Nietzsche is interested in a way how 'ressentimental' evaluations influence the form of European culture, how they lead it to a nihilistic fall. These levels are not, as it seems, equally important to him. The second one is much more elaborated in his works, what may indicate that he found it more significant. However paradoxically it may sound, Nietzsche's historiosophical-cultural considerations on the role of ressentiment in culture seem less fertile (maybe because they are factually poorly documented) than the psychological ones.

What does Nietzsche teach, then? He sketches a certain psychological genealogy of ressentiment. He claims that at the base of ressentiment, there is an overwhelming feeling of powerlessness, which emerges when the subject fails in attaining important values for them. Such a feeling of impuissance is not shared by all people but only by those, who - due to their various psychological or physical defects and the inability to create and validate their own value by themselves have a limited capability of dealing with challenges posed by reality. The reality that is tailor-made for the people free of those defects and inabilities. Thus, people

${ }^{1}$ A set of phenomena defined today as ressentiment was a subject of interest of many thinkers, e.g., David Hume - A Treatise of Human Nature, Bernard Mandeville - The Fable of the Bees, or Michel de Montaigne - Essays. 
who are weak and inept (whom he calls "slaves") must suffer, and that suffering is exceedingly painful because it stems from a negative image of one's self. According to Nietzsche, that suffering is accompanied by strong hatred, towards both the world where the unattainable values exist, and those who enjoy them.

Hatred, in a natural way, generates lust for revenge, which cannot be, in Nietzsche's opinion, directly satisfied. What precludes such satisfaction is two kinds of fear: the fear of retaliation of those to whom the vengeance is directed, and the fear of acknowledging to oneself one's inferiority, what would be questioning the value of one's self. The second type of fear is, in the case of a weak human being, the strongest. It is responsible for the fact that abandonment of discharging negative emotions (hatred, vengefulness, jaundice, jealousy, a sense of pretension) constituting the desire for revenge is not sufficient. These emotions have to be additionally repressed, eliminated from the consciousness. Thanks to that operation, their source (a particularly painful situation or a party responsible for suffering) is forgotten. The repression does not eliminate, of course, jealousy, anger, or lust for revenge. In Nietzsche's opinion, these emotions continue to exist. They become less "intelligible", less "clear", and that is why it is easier to remove them from the actual 'ressentimental' cause; it is also easier to interpret them or give them a new direction. However, the repressed emotions do not stop to imperceptibly impact the psychic; they do not cease to hurt, evoke bitterness, to fester, to make unhappy.

The man of ressentiment keeps living, one may say, in a state of an emotional split: at the surface of consciousness the intentions and feelings are bright and optimistic, but deep down in their soul there is a painful rage. The whole life of the ressentiment human is about hiding that rage, which is their natural state, their true and unadulterated nature. Hiding that nature makes their life not only painful but above all, as emphasized by Nietzsche, inauthentic. The inability of having direct vengeance, i.e., carrying out certain retaliatory acts towards real or imagined perpetrators of suffering does not mean the revenge has been abandoned. Such a resignation is utterly impossible in case of the ressentiment human because the lust for revenge is too deep to disappear just for a moment. Although the unreleased desire for revenge poisons and destroys them, it also has, as Nietzsche claims, a stimulating effect - it frees the ressentiment human from their natural passiveness and enables certain development. The starting point for such a 'ressentimental' development is a new kind of revenge that consists in a negation of the established and hostile order of values and establishing a new one, where the values become assets that guarantee advantage in life, not the cause of life failures, as before. For this new value order to be in effect, the ressentiment human does not only have to create it but also be able to enforce it onto the hostile world that 
was built upon values foreign to them. According to Nietzsche, the ressentiment human being carries it out by strengthening their own values with the power of a supernatural, otherworldly authority - unchangeable and eternal world of values, which should oblige everyone, always and everywhere. In Nietzsche's opinion, the idea of unchangeable and perfect values, apart from playing a role of metaphysical justification of the axiological order created by the ressentiment human, leads additionally to a tension which effects in division of reality into two contradictory spheres: the sphere of ahistorical and eternal truths and values, and the sphere of transient and imperfect being (that can undergo a positive evaluation only as a means to an end, which is the fullest possible proximity to the supermundane world of truth). Nietzsche further claims that this pushing of the center of gravity out of the earthly life makes such a life worthless. Not only it is not counted as the base and source of values, but, what is even worse, it becomes a synonym of all what is imperfect, evil, what one has to distance themselves from, and maybe even what should be abandoned forever. In such a way, a weak human being fences themselves from the world they lose in with the use of a full of contempt and sense of superiority distance. They look at the "unworthy world" from the heights of the "real world" (the world of the absolute truth) - the universe of objective truths. They set them free from suffering (related to inferiority they feel) for the price of living in a world of axiological illusions - threatened continuously with the deficit of faith in the created values, that is, nihilism.

Can ressentiment be used for explaining social phenomena of the contemporary world? A significant step in that direction was made by a German thinker Max Scheler, who in his ressentiment analyses joint together two perspectives: philosophical and sociological (Scheler, 1994). Within the framework of the first of these perspectives, the author of the Ressentiment clarified and developed many Nietzschean claims and analyses (not always, unfortunately, free of errors and unclarities). The way he presented how the negative emotions like jaundice, hatred, jealousy, and lust for revenge transform into ressentiment, as well as the distinction and description of developmental phases of that phenomenon should be recognized as especially explanatory valuable. In the sociological perspective, Scheler - while analyzing the causes of the emergence of ressentiment - went beyond the claims formulated by Nietzsche. For he concluded that apart from psychological factors, various aspects of social structure play an important role in the formation and further development of ressentiment. Among those aspects, he named, inter alia, age and sex structure, social role structure, social position structure.

Max Weber proposed explicitly sociological grasp of the ressentiment phenomenon (Weber, 1996). Unlike Scheler, who saw many social embodiments of ressen- 
timent, Weber linked it with the axiological activity of the lowest social classes, who believed that the reason for inequalities among "mundane fates" is the sin and injustice of the privileged groups, who earlier or later will bring God's vengeance. Ressentiment, in Weber's opinion, is manifested in ethics that include the glorification of suffering and the promise of removal of the hated social order. These ethics appreciate the suffering of the underprivileged and make them see in it a particular God-sent mission - the source of their virtue and dignity.

Contrary to the "classics" of the ressentiment research - Nietzsche and Scheler, who, in essence, considered it solely theoretically, the contemporary thinkers try more and more often to ground their analyses empirically. It is worthwhile to mention here Leon Wurmser's research presented, inter alia, in the following publications: Gedanken zur Psychopathologie von Scham und Ressentiment (1988), or Die zerbrochene Wirklichkeit. Psychoanalyse als das Studium von Konflikt und Komplementarität (2001). In his research, based, among other things, on some analyses of individual cases, Wurmser focuses mainly on a closer definition of factors conditioning the emergence of ressentiment. Contrary to Nietzsche and Scheler, who found the source of ressentiment in the feeling of inferiority, Wurmser sees it in the "wounded sense of justice", which transpires in a situation when loyalty towards the chosen authority brings no proper and expected reciprocation from its side. In such cases, apart from indignation and shame - feelings that trigger the need for the "mask" - pretending, lying, leading on - there appears, according to Wurmser, a strong need for power that generates characteristic for ressentiment absolutistic moral claims - the tool for future condemnations and rejections. There were also some attempts to develop reflection on the ressentiment phenomenon in the paradigm of not qualitative but quantitative empirical studies. Good examples here are the papers of Ramón León, Cecilia Romero, Joaquín Novara, Enrique Quesada, Roxana Gómez Sánchez, Dante Gazzolo, and Carlos Aldana published in the book entitled Estudios acerca del resentimiento (León \& Romero, 1990). These studies were, however, quite occasional and not enough theoretically grounded.

Although (as pointed above) the ressentiment category was used mainly in philosophy, sociology, or psychology, in my opinion, its explanatory capabilities exceed those disciplines. So far, it has been recognized by a few researchers (Langman \& Morris, 2002). Still, it is easy to see, even by what can be said about the phenomenon within those disciplines, that it is ideally suited for explaining so broadly disputed phenomena like fundamentalism, fanaticism, extremism, and terrorism. I shall try to elucidate these explanatory capabilities with an example of a strategy that is immanently related to the category of ressentiment. That strategy is a revaluation of values. 
This strategy consists in belittling the desired but unattainable values, and in establishing new ones, which allow to perceive oneself (a 'ressentimental' agent) in a positive light and give chances for success. There is no negation of the value of a given thing in that strategy - what is believed in is that a particular value (that is desired) is not a positive value, so what follows is a negative approach towards specific manifestations of the value (regardless of who is its bearer).

Can revaluation of values be used for explaining the phenomenon of political violence, including, e.g., Muslim violence? Undoubtedly, it is not difficult to find values related to the revaluation framework. Let us begin with the overarching value that is a starting point for all ressentiment feelings and emotions. This value is, of course, power. Power is a success (usually leading to the access to certain material resources), respect of other people, a sense of agency. Nowadays that success coexists with possessing specific values that may be called base or original. There are individualism, hedonism, secularity, democracy, freedom to individual self-determination, materialism. When power becomes, due to whatever reasons, unattainable (the lack of education, money, or cultural competencies may be an obstruction here), the values it was related to (original values) must be revalued and rejected. Their place is taken now by the secondary values - artificially created, and which were not originally desired - asceticism, communal hierarchy, tradition, modesty, afterlife orientation. The secondary values are a product of real compensation. They are characterized by their opposability towards the original values (they are, in a way, their contradiction). It is essential that they were easily accessible for the 'ressentimental' agent; they cannot become a subject of disappointment or frustration. That is why they usually are an element of tradition, "cultural equipment" of a given group or community, a 'ressentimental' life belt waiting to be used.

The essence of revaluation is a falsification of desires. The ressentiment human being has to convince themselves that their former desires directed towards unreachable values were a mistake, the new ones, however, are rightly directed, proper, and genuinely authentic. If they succeeded in effectively carrying out the operation on the desires, i.e., if they were able to erase from their consciousness the original values and replace them with the fabricated (artificially created) secondary desires, they would undoubtedly be successful. However, the problem is that the original desires embody that what is truly wished for and the secondary desires are imaginary creations (born in the fight for maintaining self-assessment), and hence inauthentic, wobbly, weak - that is why revaluation of values can never be fully effective.

There is no question that instability of the secondary axiological preferences and emotional dissonance have to generate doubts in the 'ressentimental' agent 
regarding the integrity of the created value system. Therefore, it can be expected that the next element of the strategy will be the necessity to justify those values - gaining certainty through creating metaphysical references to the Absolute that the system of 'ressentimentally' constituted values is the only correct and true one. As noted by Richard Smith, the ressentiment human being must continuously evoke in themselves the faith that their way of looking at the world and evaluating it is right and unquestionable. However, they do not always do it earnestly - they selectively collect information about the reality, ignore unfavorable parts, deny disturbing facts - so that no doubt regarding the value of the chosen system enters their consciousness (Smith, 1993). That drive for justification at any cost kills the spirit of skepticism (a healthy need for criticism).

However, fundamentalism is not easily cultivated. It is always in danger of engaging in a confrontation with other fundamentalisms and their justifications. Moreover, in such a situation some new doubts may appear - this time about the exceptional and absolute status of the fundamentalist justifications (Posłuszny, 2012). How can one, in such a situation, keep the justifications? Insight on that can be found in the research conducted by Leon Festinger, Henry W. Riecken, and Stanley Schachter (2008). The goal of their study was a verification of the presuppositions of the cognitive dissonance theory. The subject researched was a sect convinced that on December $21^{\text {st }}, 1954$ the world would come to an end due to a massive flood. The only ones to avoid this dire end were the sect members, who were to be saved by alien creatures from the planet Clarion. These creatures were supposed to transfer them to a safe place in their flying saucers. During their preparations for the galactic trip, the sect members left their jobs, dished out their money and possessions, and even abandoned their loved ones. When the date of the global catastrophe was approaching, quiet and rather closed group began actively recruiting new members and conduct various propaganda actions, which they avoided before ${ }^{2}$. On December $21^{\text {st }}$, when the prophecy did not come to pass, contrary to common-sense expectations the members (after a short breakdown and subsequent rationalization according to which the Earth was spared from the cataclysm due to firm faith of the worshippers) did not abandon their faith. On the contrary, they very actively (one may say fanatically) started to spread it.

Festinger does not provide deepened psychological explanations in his studies. It is not his intention. However, it does not change the fact that there is a particular analogy between the case he described and our considerations that prompt a hypothesis regarding the sources of fanaticism (a hypothesis that should be fur-

\footnotetext{
${ }^{2}$ For example, contacts with the press, radio, and television were established.
} 
ther examined, also empirically). Following the path opened up by Festinger, and extrapolating the conclusions of his research on issues important for these considerations, one may presume that in a situation when fundamentalist values and their justifications cannot withstand when facing doubts provided by other fundamentalisms (other competitive visions of the world), the faith in their metaphysical justification deepens. That faith is followed by a fanatic activity (in the spiritual and physical domain), which aim is to disperse the arisen doubts. This fanatic activity is not only (as it was the case with fundamentalism) an intellectual precaution against doubts generated by the agent themselves but a reaction to external threats that may result in losing the faith. When the threats are serious, when they strongly affect the worldview built on the basis of the secondary values, they have to bring about frustration (related to the pain of inferiority), which in turn transforms, in favorable circumstances, into aggression and violence $e^{3}$. This is, of course, a hypothesis. Still, it provides, as it seems, a picture of possibilities how the ressentiment category can be employed in research conducted in Security Studies.

Readiness for radical actions does not stem only from the nature of the characteristic features of a particular extremism. As I wrote before, behind such willingness usually there is a complex system of defense mechanisms, which quite often are a reaction on the experienced feeling of resentment. Resentment seems to be a psychic power that forces individuals and groups to overcome, in the name of maintaining the identity and positive self-image, a conformist anxiety and become what they want to become - the sole and the true creators of values and communal sense. In their case, reaching for violence becomes a way of dealing with both arising doubts and the resistance of the world reluctant toward these values. Due to the fact that the essence of resentment is a pursuit toward reevaluating the values (depreciation of the existing values and establishing the new, resentful ones), it has to lie at the foundation of the acts, which aim at total social transformations. For resentment as such does not aim at a change of some part of reality but at a transformation of the world in its entirety. It is impossible to control terrorism based on resentment by concession and negotiations because it is not interested in them. Resentment terrorism aims at total (uncompromising) changes. It aims also at destruction of all old order residua (symbols of unattained values) which, on the account of resentment, it feels connected to. Where there is a black and white reality, there is no place for attempts to come to an agreement or

${ }^{3}$ Whether it comes to that depends on many factors, especially on if within the ideology fundamentalism refers to violence is accepted or condemned (whether there are incentives to disperse frustration in other non-violent forms). 
any kind of actions based on the idea of compromise. Therefore, it probably occurs more often in terrorism of the revolutionary type than in single-issue terrorism. The latter, contrary to the former one, makes no total, transformational claims because it is focused on carrying out a single issue - on dealing with merely one particular fragment of reality (unless it is allied with a "transformational" ideology). Hence, it must be non-fundamentalist in its essence (i.e., resentment plays, if any, a marginal role in its forming). If this conception is right, then there is a high probability that after carrying out that issue (or at least after introducing a number of compromise solutions), terrorism would be extinguished or at least largely reduced. Such a perspective seems impossible in the case of revolutionary terrorism (wide-ranged, resentful) that aims at total social transformation. For revolutionary terrorism these issues are only a pretext for the articulation of internal, stimulated by inferiority instinct, transformational claims. The need behind it (the need to devaluate the world that depreciates the "I") is indeed unchangeable and always stays current - that is why fulfilling the articulated claims is not able to satisfy it. In the fight against resentful terrorism possible are, as it seems, only preventive actions but they should be undertaken much earlier - before resentment enters the phase of reevaluation of values.

The above - rather superficial - review of theories of ressentiment shows that this phenomenon, due to its complexity and multifaceted nature, has extraordinary explanatory power. Of course, examining it has to be full of obstacles. The two broadest and most famous analyses - the concepts of Nietzsche and Scheler - are difficult to use as a basis for reliable empirical studies. It is also plausible that it would be difficult to quantitatively examine the phenomenon itself. Maybe what is attainable is just a theoretical reflection. If so, it does not have to be an idle one. On the contrary, it may turn out to be exceptionally prolific, especially because there is still a lot to work on. Thus, one may risk a claim that a progress of academic reflection on the ressentiment phenomenon requires further clarification of still not very precisely expressed concepts of ressentiment joined with deep analyses of its genealogy and possible consequences.

\section{References:}

Brachfeld, O. (1972). Inferiority Feelings: In the Individual and the Group. Westport: Greenwood Press.

Festinger, L., Riecken, H.W., \& Schachter, S. (2008). When Prophecy Fails. London: Printer \& Martin.

Feyerabend, P.K. (2001). Przeciw metodzie. Wrocław: Wydawnictwo Siedmioróg. 
Kaufmann, W.A. (1968). Nietzsche: Philosopher, Psychologist, Antichrist. Princeton, New Jersey: Princeton University Press.

Klages, L. (1977). Die psychologischen Errungenschaften Nietzsches. Bonn: Bouvier Verlag Herbert Grundmann.

Langman, L., \& Morris, D. (2002). Islamic Terrorism: From Retrenchment to Ressentiment and Beyond. In: H.W. Kushner (ed.). Essential Readings on Political Terrorism: Analyses of Problems and Prospects for the 21 $1^{\text {st }}$ Century (pp. 130-184). New York: Richard Altschuler \& Associates.

León, R., \& Romero, C. (1990). Estudios acerca del resentimiento. Consejo, Lima: Nacional de Ciencia y Tecnología.

Nietzsche, F. (1996). On the Genealogy of Morals. Oxford: Oxford University Press.

Posłuszny, J. (2012). Nienawistna wrogość. Szkice z filozofii bezpieczeństwa. Warszawa: Difin.

Scheler, M. (1994). Ressentiment. Milwaukee: Marquette University Press.

Smith, R.A. (1993). Nietzsche: Philosopher of Ressentiment? International Studies in Philosophy, 25(2), 135-143. DOI: 10.5840/intstudphil199325273.

Tesser, A, (1988). Toward a Self-Evaluation Maintenance Model of Social Behaviour. In: L. Berkowitz (ed.). Advances in Experimental Social Psychology (Vol. 21, pp. 181-227). San Diego, CA: Academic Press.

Weber, M. (1996). The Sociology of Religion. Boston: Beacon Press.

Wurmser, L. (1988). Gedanken zur Psychopathologie von Scham und Ressentiment. Analytische Psychologie, 19(4), 283-306. DOI: 10.1159/000471239.

Wurmser, L. (2001). Die zerbrochene Wirklichkeit. Psychoanalyse als das Studium von Konflikt und Komplementarität. Göttingen: Vanenhoeck \& Ruprecht. 